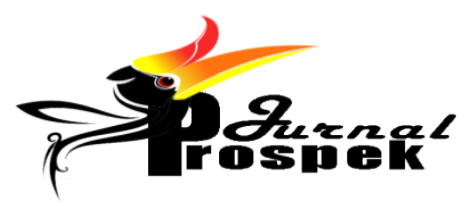

http://e-journals.unmul.ac.id/index.php/jpe

Jurnal Prospek : Pendidikan Ilmu Sosial dan Ekonomi

Volume 3 No 1 Juli 2021

E-ISSN 2721-0855

\title{
HUBUNGAN KOMPETENSI GURU DENGAN NILAI UJIAN NASIONAL DI SMK NEGERI 4 SAMARINDA TAHUN PEMBELAJARAN 2018/2019
}

\author{
Dewi Agnesia \\ Universitas Mulawarman \\ dewiagnesia15@gmail.com \\ Made Ngurah Partha \\ Universitas Mulawarman \\ made.ngurah@fkip.unmul.ac.id \\ Nasib Subagio \\ Universitas Mulawarman \\ nasib.subagio@fkip.unmul.ac.id
}

\begin{abstract}
This study aims to determine the relationship of teacher competence with the national exam scores in SMK 4 Samarinda in 2018/2019. This study uses a quantitative approach, and was carried out in SMK Negeri 4 Samarinda. The data used is the data of national exam scores in the 2018/2019 with the method of questionnaire and documentation. Analysis of the data used is the product moment correlation analysis and significant testing using the $t$ test. The results showed the teacher competence correlation coefficient value of 0.744, when interpreted into the scale of interpretation the correlation coefficient included in the category of "Strong". The results it can be concluded that Ho is rejected and Ha is accepted, meaning that there is a significant relationship between the cost of teacher competence with the national exam scores in SMK Negeri 4 Samarinda in 2018/2019. From the research the school can organize training to further develop pedagogical and professional competencies.
\end{abstract}

Keywords: teacher competence, national exam scores

Abstrak: Penelitian ini bertujuan untuk mengetahui hubungan kompetensi guru dengan nilai
ujian nasional di SMK Negeri 4 Samarinda Tahun pembelajaran 2018/2019. Penelitian ini
menggunakan pendekatan kuantitatif, dan dilaksanakan di SMK Negeri 4 Samarinda. Data
yang digunakan adalah data nilai ujian nasional pada tahun Pembelajaran 2018/2019 dengan
metode Angket dan dokumentasi. Analisis data yang digunakan adalah analisis korelasi
product moment dan pengujian signifikan menggunakan uji t. Dari hasil tersebut dapat
disimpulkan bahwa Ho ditolak dan Ha diterima, artinya ada hubungan yang signifikan antara
kompetensi guru dengan nilai ujian nasional di SMK Negeri 4 Samarinda tahun pembelajaran
2018/2019. Dari hasil penelitian pihak sekolah dapat menyelenggarakan pelatihan agar lebih
mengembangkan kompetensi pedagogik dan kompetensi profesional. Kata Kunci : kompetensi guru, nilai ujian nasional 


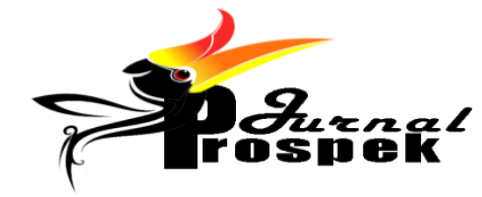

http://e-journals.unmul.ac.id/index.php/jpe

Jurnal Prospek : Pendidikan Ilmu Sosial dan Ekonomi

Volume 3 No 1 Juli 2021

E-ISSN 2721-0855

\section{PENDAHULUAN}

Ujian Nasional biasa disingkat UN merupakan sebuah sistem evaluasi standar pendidikan dasar dan menengah secara nasional dan persamaan mutu tingkat pendidikan antar daerah yang dilakukan oleh Pusat Penilaian Pendidikan. Dalam sejarah perkembangan ujian nasional di Indonesia telah mengalami beberapa kali perubahan baik dari istilah sampai pelaksanaannya yang di mulai dari tahun 1965 sampai sekarang. Berdasarkan Permendikbud Nomor 3 Tahun 2013 tentang kriteria kelulusan dari satuan pendidikan dan penyelenggaraan ujian sekolah/Pendidikan kesetaraan dan ujian nasional menjelaskan bahwa ujian nasional merupakan kegiatan pengukuran dan penilaian pencapaian kompetensi lulusan secara nasional pada mata pelajaran tertentu dalam kelompok mata pelajaran ilmu pengetahuan dan teknologi.

Nilai ujian nasional tidak terlepas dari peran guru, dimana guru merupakan terpenting mulai dari perencanaan pembelajaran, proses pembelajaran hingga evaluasi pembelajaran. Guru mempunyai kedudukan sebagai tenaga profesional yang dituntut untuk selalu mengembangkan diri sesuai dengan perkembangan ilmu pengetahuan dan teknologi. UndangUndang Republik Indonesia Nomor 14 Tahun 2005 tentang Guru dan Dosen menyatakan bahwa "Guru wajib memiliki kualifikasi akademik, kompetensi, sertifikat pendidik, sehat jasmani dan rohani, serta memiliki kemampuan untuk mewujudkan tujuan pendidikan nasional. Dalam ayat 1 lebih dijelaskan mengenai kompetensi yang dimaksud yaitu meliputi kompetensi pedagogik, kompetensi kepribadian, kompetensi sosial, dan kompetensi profesional yang diperoleh melalui pendidikan profesi.

Guru sebagai pendidik adalah tokoh yang paling banyak bergaul dan berinteraksi dengan para murid jika dibanding dengan personil lainnya disekolah. Guru bertugas merencanakan dan melaksanakan proses pembelajaran, menilai hasil pembelajaran, melakukan bimbingan dan pelatihan, melakukan penelitian dan pengkajian dan membuka komunikasi dengan masyarakat. Guru yang memiliki kompetensi baik, selalu berpandangan positif terhadap kualitas kemampuan yang dimiliki sehingga akan memandang seluruh tugas sebagai suatu hal yang mudah untuk diselesaikan. Kompetensi guru baik di Sekolah Menengah Atas (SMA) maupun Sekolah Menengah Kejuruan (SMK) bersifat menyeluruh dan merupakan satu kesatuan yang saling berhubungan dan saling mendukung. SMK 


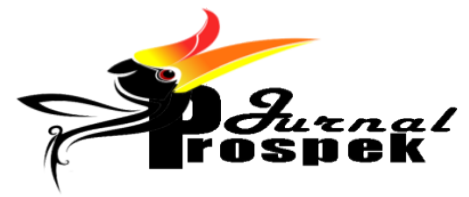

http://e-journals.unmul.ac.id/index.php/jpe

Jurnal Prospek : Pendidikan Ilmu Sosial dan Ekonomi

Volume 3 No 1 Juli 2021

E-ISSN 2721-0855

Negeri 4 Samarinda adalah salah satu SMK yang memiliki 6 program keahlian yang terbagai kedalam 10 kelas. Jumlah guru pada program keahlian adalah sebanyak 31 orang dan guru mata pelajaran umum sebanyak 32 orang. Dalam pelaksanaan ujian nasional, SMK Negeri 4 Samarinda mampu mencapai angka kelulusan 100\%. Peserta ujian nasional di SMK Negeri 4 Samarinda dinyatakan lulus jika memenuhi standar kelulusan 75.

Berdasarkan observasi awal diperoleh data rerata nilai ujian nasional SMK Negeri 4 Samarinda sebagai berikut:

\section{Tabel 1 Rerata Nilai Ujian Nasional SMKN 4 Samarinda}

\begin{tabular}{llllllll}
\hline \multirow{2}{*}{ No } & Tahun & $\begin{array}{c}\text { Jumlah } \\
\text { Peserta } \\
\text { Didik }\end{array}$ & $\begin{array}{l}\text { Bahasa } \\
\text { Indonesia }\end{array}$ & $\begin{array}{l}\text { Bahasa } \\
\text { Inggris }\end{array}$ & Matematika & $\begin{array}{c}\text { Kompeten } \\
\text { si }\end{array}$ & Rerata \\
\hline 1. & 2017 & 333 & 71.47 & 51.44 & 42.67 & 81.37 & 61.74 \\
\hline 2. & 2018 & 338 & 74.55 & 59.57 & 40.83 & 54.77 & 57.43 \\
\hline 3. & 2019 & 370 & 72.40 & 51.90 & 37.79 & 50.57 & 53.17 \\
\hline
\end{tabular}

Sumber: Tata Usaha SMKN 4 Samarinda (2019)

Rerata nilai ujian nasional di SMK Negeri 4 Samarinda dari tahun 2017 sampai dengan 2019 selalu mengalami penurunan di setiap tahunnya, padahal tidak dapat dipungkiri hasil ujian nasional dapat menentukan bagaimana suatu sekolah dipandang oleh masyarakat dan juga sekolah lain. Rerata nilai ujian nasioal pada setiap mata pelajaran adalah berbedabeda, rerata nilai terendah adalah pada mata pelajaran matematika yaitu 37,79 pada tahun 2019 dan rerata nilai tertinggi disetiap tahunnya adalah pada mata pelajaran Bahasa Indonesia. Perbedaan nilai tersebut tentunya menunjukkan bagaimana pemahaman peserta didik pada setiap mata pelajaran.

Salah satu faktor eksternal yang mempengaruhi nilai ujian nasional peserta didik adalah kompetensi yang dimiliki seorang guru sebagai pengajar. Aquami dan Handayani (2018) dalam penelitiannya menyimpulkan bahwa terdapat hubungan yang signifikan antara kompetensi guru dan peran orang tua terhadap hasil belajar siswa. Namun hasil yang berbeda diperoleh pada penelitian lain yang dilakukan Juhadi dan Santoso (2015) yang menyimpulkan bahwa tidak ada hubungan positif yang signifikan antara nilai Uji Kompetensi Guru dengan nilai rata-rata Ujian Nasional Tahun 2013 di SMA Se-Kota Semarang.

Berdasarkan perbedaan hasil penelitian tersebut disertai kondisi nilai ujian nasional peserta didik di SMK Negeri 4 Samarinda menjadikan peneliti ingin mengetahui apakah 


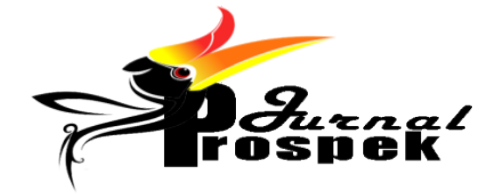

http://e-journals.unmul.ac.id/index.php/jpe

Jurnal Prospek : Pendidikan Ilmu Sosial dan Ekonomi

Volume 3 No 1 Juli 2021

E-ISSN 2721-0855

kompetensi guru di SMK Negeri 4 Samarinda berhubungan dengan pemahaman siswa yang pada akhirnya berdampak pada nilai ujian nasional.

\section{METODE}

Penelitian ini menggunakan jenis penelitian kuantitatif. Pengumpulan data menggunakan instrumen Kuisioner dan Dokumentasi. Populasi dalam penelitian ini adalah seluruh guru di SMK Negeri 4 Samarinda dan Sampel penelitian ini seluru guru mata pelajaran yang diujikan dalam ujian nasional. Teknik analisis data yang digunakan teknik analisis korelasi product moment, uji t dan Koefisien Determinasi.

\section{HASIL}

Analisis Korelasi Product Moment

Analisis yang digunakan dalam penelitian ini adalah Korelasi Product Momen dengan menggunakan SPSS. Berikut merupakan tabel hasil pengujian untuk menentukan persamaan korelasidengan menggunakan SPSS.

Tabel 2 Korelasi Product Moment

\begin{tabular}{l|l|l|l}
\hline \multicolumn{2}{l}{ Correlations } & Kompetensi_guru & Nilai_ujian_nasional \\
\hline \multirow{2}{*}{ Kompetensi_guru } & $\begin{array}{l}\text { Pearson } \\
\text { Correlation }\end{array}$ & 1 & .744 \\
\cline { 2 - 4 } & Sig. (2-tailed) & & .047 \\
\cline { 2 - 4 } & $\mathrm{N}$ & 30 & 30 \\
\hline \multirow{2}{*}{$\begin{array}{l}\text { Nilai_ujian_nasion } \\
\text { al }\end{array}$} & $\begin{array}{l}\text { Pearson } \\
\text { Correlation }\end{array}$ & .744 & 1 \\
\cline { 2 - 4 } & Sig. (2-tailed) & .047 & 360 \\
\cline { 2 - 4 } & $\mathrm{N}$ & 30 & \\
\hline
\end{tabular}

Sumber: Data diolah (2020)

Berdasarkan tabel korelasi product moment tersebut maka dapat diketahui nilai koefisien korelasi kompetensi guru dengan nilai ujian nasional adalah sebesar 0.744, dimana pada tabel interpretasi koefisien korelasi nilai tersebut berada pada rentang nilai 0,60-0,799. Berdasarkan hasil tersebut dapat diketahui bahwa hubungan antara kompetensi guru dengan nilai ujian nasional di SMK Negeri 4 Samarinda dapat diinterpretasikan kedalam tingkat hubungan "Kuat". 


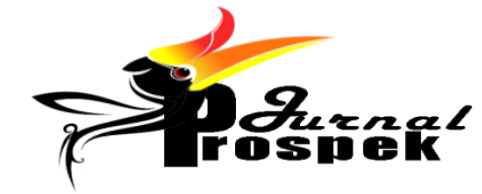

http://e-journals.unmul.ac.id/index.php/jpe

Jurnal Prospek : Pendidikan Ilmu Sosial dan Ekonomi

Volume 3 No 1 Juli 2021

E-ISSN 2721-0855

Uji t dilakukan pada variabel kompetensi guru terhadap variabel nilai ujian nasional secara parsial. Adapun rincian nilai signifikansi dari masing-masing variabel independen ditunjukkan pada tabel berikut:

Tabel 3 Hasil Uji t

\begin{tabular}{|c|c|c|c|c|c|c|}
\hline \multicolumn{7}{|c|}{ Coefficients $^{\mathbf{a}}$} \\
\hline & & \multicolumn{2}{|c|}{$\begin{array}{l}\text { Unstandardized } \\
\text { Coefficients }\end{array}$} & \multirow{2}{*}{$\begin{array}{c}\begin{array}{c}\text { Standardized } \\
\text { Coefficients }\end{array} \\
\text { Beta } \\
\end{array}$} & \multirow[b]{2}{*}{$\mathrm{t}$} & \multirow[b]{2}{*}{ Sig. } \\
\hline \multicolumn{2}{|c|}{ Model } & $\mathrm{B}$ & Std. Error & & & \\
\hline \multirow[t]{2}{*}{1} & (Constant) & 9.172 & 4.021 & & 2.880 & .008 \\
\hline & Kompetensi_guru & .200 & 289 & .130 & 1.994 & .034 \\
\hline
\end{tabular}

a. Dependent Variable: Nilai_ujian_nasional

Sumber: Data diolah (2020)

Hasil pengujian SPSS diperoleh hasil uji t dari nilai tingkat signifikan (Sig) pada variabel independen menunjukkan bahwa variabel kompetensi guru memiliki nilai $t_{\text {hitung }}=$ 1.994, dan nilai $\mathrm{t}_{\text {tabel }}=1.701$ pada $\mathrm{df}=28$ dengan tingkat signifikan sebesar 0,05 . Karena $t_{\text {hitung }}>\mathrm{t}_{\text {tabel }}(1.994>1.701)$ maka $\mathrm{H}_{0}$ ditolak dan $\mathrm{H}_{\mathrm{a}}$ diterima, sehingga secara parsial ada hubungan yang signifikan antara kompetensi guru dengan Nilai Ujian Nasional di SMK Negeri 4 Samarinda tahun ajaran 2018/2019

Nilai Koefisien Determinasi $\left(\mathrm{R}^{2}\right)$

Besarnya hubungan variabel independen yaitu kompetensi gurudengan variabel dependen yaitu nilai ujian nasional dapat dilihat dari nilai Adjusted R-Square yaitu:

Tabel 4 Hasil Uji Koefisien Determinasi $\left(R^{2}\right)$

\begin{tabular}{|c|c|c|c|c|c|}
\hline \multicolumn{6}{|c|}{ Model Summary } \\
\hline Model & $\mathrm{R}$ & R Square & $\begin{array}{l}\text { Adjusted R } \\
\text { Square }\end{array}$ & $\begin{array}{l}\text { Std. Error of } \\
\text { the Estimate }\end{array}$ & $\begin{array}{l}\text { R Square } \\
\text { Change }\end{array}$ \\
\hline 1 & $.130^{\mathrm{a}}$ & .617 & .718 & 2.65243 & .617 \\
\hline
\end{tabular}

a. Predictors: (Constant), Kompetensi_guru

b. Dependent Variable: Nilai_ujian_nasional

Sumber: Data diolah (2020)

Berdasarkan hasi olah data dengan SPSS dapat diketahui nilai adjusted $\mathrm{R}$ Squaresebesar 0,71 artinya bahwa variabel bebas yaitu kompetensi guru mempunyai kemampuan sebesar 71\% untuk menjelaskan hubungannya terhadap variabel terikat yaitu nilai ujian nasional. Sedangkan sisanya sebesar 29\% dijelaskan oleh variabel lain yang tidak 


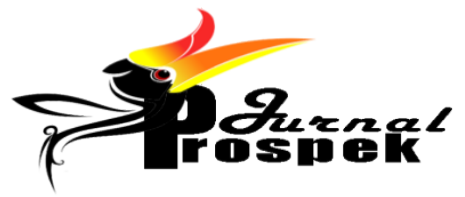

http://e-journals.unmul.ac.id/index.php/jpe

Jurnal Prospek : Pendidikan Ilmu Sosial dan Ekonomi

Volume 3 No 1 Juli 2021

E-ISSN 2721-0855

dimasukkan dalam penelitian. Karena diperoleh nilai $\mathrm{R}^{2}$ sebesar 0,72 sudah mendekati 1 , maka dapat disimpulkan bahwa variabel bebas cukup kuat dalam menjelaskan variabel terikat.

\section{PEMBAHASAN}

Berdasarkan hasil penelitian dapat diketahui bahwa ada hubungan yang signifikan antara kompetensi guru dengan nilai ujian nasional SMK Negeri 4 Samarinda, hal tersebut dibuktikan dengan hasil analisis korelasi product moment sebesar 0.744. Hasil perhitungan tersebut dapat di interprestasikan dengan menggunakan skala interprestasi yang sudah ditetapkan. Maka diketahui hubungan kompetensi guru dengan nilai ujian nasional di SMK Negeri 4 Samarinda tahun pembelajaran 2018/2019 bila diinterpresikan kedalam skala interprestasi koefisien korelasi termasuk dalam kategori “ Kuat”, dimana angka tersebut terletak antara 0,60-0,799. Hasil penelitian tersebut mendukung penelitian Hazami dan Hermaningsih (2017) bahwa variabel kompetensi guru berpengaruh signifikan dan positif terhadap peningkatan efektifitas pembelajaran di sekolah sehingga berdampak pada prestasi belajar siswa menjadi lebih baik. Putri dan Suwatno (2017) dalam penelitiannya juga menunjukkan bahwa kompetensi pedagogik dan kompetensi sosial berpengaruh positif dan signifikan terhadap prestasi belajar siswa.

Kompetensi guru dalam penelitian ini dilihat dari 4 kompetensi yang harus dimiliki seorang guru. Dari hasil perhitungan kuisioner dengan mencari mean dan persentase jawaban responden mengenai kompetensi pedagogik, maka diperoleh nilai rata-rata pada kompetensi pedagogik sebesar 3,2 dan termasuk dalam kategori tinggi. Rusman (2013:54) menyatakan bahwa kompetensi pedagogik meliputi pemahaman terhadap peserta didik, perencanaan dan pelaksanaan kegiatan pembelajaran, evaluasi hasil belajar dan pengembangan peserta didik untuk mengaktualisasikan berbagai potensi yang dimiliki. Dalam penelitian ini kompetensi pedagogik dijabarkan menjadi 9 item pernyataan yang harus dilakukan oleh seorang guru. Berdasarkan rata-rata jawaban responden, 62\% responden menjawab "Sering” melaksanakan tindakan yang mendukung penguasaan kompetensi pedagogik, diantaranya guru berusaha memahami kemampuan dasar peserta didik, guru menyadari bahwa setiap peserta didik memiliki minat dan keamampuan yang berbeda. Guru juga sangat memperhatikan proses pembelajaran dengan menggunakan media pembelajaran serta mengembangkan bahan ajar. 


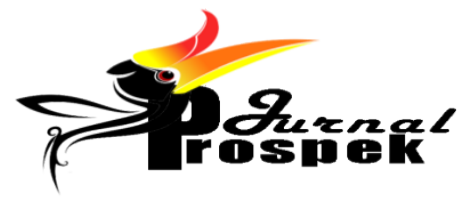

http://e-journals.unmul.ac.id/index.php/jpe

Jurnal Prospek : Pendidikan Ilmu Sosial dan Ekonomi

Volume 3 No 1 Juli 2021

E-ISSN 2721-0855

Disisi lain sebanyak 37\% guru di SMK Negeri 4 Samarinda dikatakan "Selalu" melakukan kegiatan yang terkait dengan kompetensi pedagogik. Dalam proses pembelajaran guru selalu melibatkan peserta didik dalam pembuatan dan pemanfaatan sumber belajar, dan di akhir pembelajaran guru juga selalu melaksakan evaluasi pembelajaran.

Temuan diatas sesuai dengan Dalam PP No. 74 tahun 2008 pasal 3 ayat (4) bahwa kompetensi pedagogik merupakan kemampuan pemahaman terhadap peserta didik, penguasaan teori belajar dan prinsip-prinsip pembelajaran, pengembangan peserta didik untuk mengaktualisasikan berbagai potensi yang dimilikinya, memanfaatkan teknologi informasi dan komunikasi untuk kepentingan pembelajaran, dan evaluasi hasil belajar. Asmani (2009:59) bahwa kompetensi utama yang harus dimiliki guru agar pembelajaran efektif dan dinamis adalah kompetensi pedagogik. Hal ini berarti bahwa guru dengan kemampuan pedagogik yang diperoleh melalui proses pendidikan dan proses belajar tentang bagaimana penerapan mendidik dan ilmu mendidik sangat menentukan tercapainya nilaiujian nasional yang baik di SMK Negeri 4 Samarinda.

Kompetensi kedua yang harus dimiliki guru adalah kompetensi kepribadian. Berdasarkan hasil penelitian kompetensi kepribadian mendapat nilai rata-rata sebesar 3,4 dengan kategori tinggi. Dari jawaban responden dapat diketahui 53,8\% guru dikatakan “Selalu” melakukan kegiatan yang mencerminkan kompetensi kepribadian yang baik. Salah satu item pernyataan yang mendapatkan nilai tertinggi adalah guru selalu berpegang teguh pada norma, artinya guru mampu menempatkan diri sebagai panutan bagi peserta didik dalam mematuhi norma-norma yang berlaku. Sehingga dalam setiap permasalahan guru selalu menyelesaikannya dengan tenang dan tidak emosional, hal tersebut juga menjadi teladan yang baik bagi peserta didiknya.

Beberapa hal lainnya yang menunjukkan kepribadian dapat diketahui sebesar 44,4\% dengan kategori “Sering” dilakukan oleh guru di SMK Negeri 4 Samarinda, diantaranya guru mampu mengendalikan suasa dalam pembelajaran, pembawaan yang tegas namun santun mampu membuat peserta didik patuh dengan aturan guru saat di dalam kelas. Guru juga selalu menghargai perbedaan, bagi dari latar belakang peserta didik, pendapat maupun jawaban dari setiap peserta didik. 


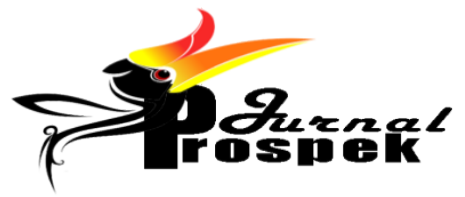

http://e-journals.unmul.ac.id/index.php/jpe

Jurnal Prospek : Pendidikan Ilmu Sosial dan Ekonomi

Volume 3 No 1 Juli 2021

E-ISSN 2721-0855

Selanjutnya adalah kompetensi sosial dengan nilai rata-rata sebesar 4 dengan kategori sangat tinggi. Dari 4 item pernyataan responden menjawab bahwa 72,5\% pernyataan tersebut “Selalu” dilakukan guru di SMK Negeri 4 Samarinda. Guru selalu berkomunikasi dengan cara yang baik, tidak hanya kepada sesama guru melainkan juga saat berkomunikasi dengan peserta didik. Hasl tersebut seosuai dengan penjelasan Alma (2010:128) bahwa kompetensi sosial mencakup kemampuan guru untuk menyesuaikan diri kepada tuntutan kerja dan lingkungan sekitar pada waktu membawakan tugasnya sebagai seorang guru.Guru juga selalu mampu memposisikan dirinya, tidak hanya sebagai teladan tetapi guru juga bisa sebagai teman disaat peserta didik ingin membegi masalah yang dihadapi.

Terdapat pula 26,6\% dari empat item pernyatan yang hanya dilakukan pada kategori "Sering", diantaranya guru menumbuhkan antusiasme peserta didik dalam berbagai hal. Tidak cukup bahwa guru mampu membuat peserta didik antusias untuk belajar, namun guru juga harus mampu untuk menumbuhkan antusiasme peserta didik untuk mengembangkan potensi yang dimiliki. Hal tersebut lah yang masih belum dilakukan secara maksimal oleh guru di SMK Negeri 4 Samarinda.

Kompotensi yang terakhir adalah kompetensi profesional, yang memperoleh nilai rata-rata sebesar 3,3 dengan kategori tinggi. Dari rata-rata jawaban responden, 68\% dari 7 item pertanyaan adalah sering dilakukan oleh guru di SMK Negeri Samarinda. Dalam proses pembelajaran guru selalu menguasai materi dan memahami materi dengan baik, guru mampu mengaitkan materi dengan realita yang ada disekitar peserta didik. Selain itu dalam proses pembelajaran guru juga selalu memanfaatkan internet sebagai sumber belajar. Selain mengembangkan potensi peserta didik, guru di SMK Negeri 4 Samarinda juga sering mengikuti kegiatan yang mendukung potensi serta profesinya, diantaranya guru melakukan penelitian ilmiah dan menguasai langkah-langkah dalam melaksanakan penelitian.

Kompetensi yang dimiliki oleh seorang guru tentunya akan berdampak pada hasil belajar peserta didik, hal ini didukung dengan pendapat Aunurrahman (2010:187) yang menyatakan bahwa keberhasilan belajar siswa ditentukan oleh faktor internal dan faktor eksernal, dimana faktor eksternal yang mempengaruhi hasil belajar siswa adalah faktor guru, lingkungan sosial, kurikulum sekolah. Faktor tersebut erat hubungannya dengan aktivitas guru dalam kegiatan pembelajaran. Kompetensi pedagogik merupakan kompetensi yang 


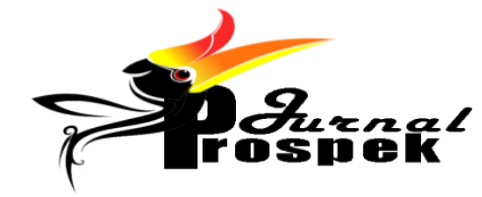

http://e-journals.unmul.ac.id/index.php/jpe Jurnal Prospek : Pendidikan Ilmu Sosial dan Ekonomi

Volume 3 No 1 Juli 2021

E-ISSN 2721-0855

paling erat kaitannya dengan nilai peserta didik, dimana kompetensi pedagogik mengharuskan guru untuk melakukan pemahaman terhadap peserta didik, perencanaan dan pelaksaan kegiatan pembelajaran, evaluasi hasil belajar dan pengembangan peserta didik untuk mengaktualisasikan berbagai potensi yang Kompetensi pedagogik yang dimiliki guru SMK Negeri 4 Samarinda mendapatkan nilai rata-rata paling rendah sehingga berdampak pada nilai ujian nasional peserta didik. Nilai Ujian Nasional dilihat dari nilai pada empat mata pelajaran yang di ujikan. Nilai ujian nasional dalam kategori sangat baik diperoleh sebanyak 9 siswa, untuk kategori baik diperoleh sebanyak 213 siswa dengan skor antara 70 - 85, nilai kategori cukup sebanyak 138 siswa dengan skor antara 55 - 70, dan tidak ada siswa yang mendapatkan skor antara 0 - 55. Dari hasil tersebut dapat dilihat bahwa nilai ujian nasional yang dimiliki peserta didik SMK Negeri 4 Samarinda hanya dominan pada kategori baik cukup.

Berdasarkan temuan dari hasil penelitian tersebut, kompetensi pedagogik guru di SMK Negeri 4 Samarinda perlu terus ditingkatkan. Jika kompetensi pedagogik yang dimiliki guru meningkat maka niali ujian nasional peserta didik tidak hanya dominan di baik dan cukup, tapi diharapkan mampu meningkat pada kategori sangat baik. Peningkatan kompetensi pedagogik tentunya perlu diikuti dengan peningkatan kompetensi yang lainnya.

Berdasarkan hasil uji hipotesis yang dilakukan dengan uji t, diperoleh nilai $\mathrm{t}_{\text {hitung }}=$ 1.994, dan nilai $t_{\text {tabel }}=1.701$ pada $\mathrm{df}=28$ dengan tingkat signifikan sebesar 0,05 . Karena $t_{\text {hitung }}>\mathrm{t}_{\text {tabel }}(1.994>1.701)$ maka $\mathrm{H}_{0}$ ditolak dan $\mathrm{H}_{\mathrm{a}}$ diterima, sehingga secara parsial ada hubungan yang signifikan antara kompetensi guru dengan Nilai Ujian Nasional di SMK Negeri 4 Samarinda tahun ajaran 2018/2019. Hasil tersebut sejalan dengan penelitian yang dilakukan Aquami dan Handayani (2018) yang menyimpulkan bahwa terdapat hubungan yang signifikan antara kompetensi guru dan peran orang tua terhadap hasil belajar siswa MIN 2 Palembang. Hasil yang sama juga diperoleh pada penelitian yang dilakukan Syaidah, Suyadi dan Ani (2018) bahwa kompetensi guru mempunyai pengaruh yang signifikan terhadap hasil belajar ekonomi di SMA Negeri Rambipuji Tahun Ajaran 2017/2018. 


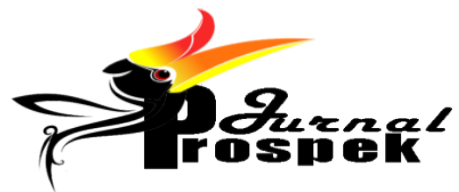

http://e-journals.unmul.ac.id/index.php/jpe

Jurnal Prospek : Pendidikan Ilmu Sosial dan Ekonomi

Volume 3 No 1 Juli 2021

E-ISSN 2721-0855

\section{KESIMPULAN}

Berdasarkan hasil pembahasan mengenai Hubungan Kompetensi guru dengan Nilai Ujian Nasional di SMK Negeri Samarinda tahun pembelajaran 2018/2019 maka dapat disimpulkan bahwa:

1. Terdapat Hubungan antara Kompetensi Guru dengan nilai ujian nasional di SMK Negeri 4 Samarinda. Hal ini dapat dilihat dari nilai koefisien korelasi (R) sebesar 0.74. Jika hasil tersebut diinterpretasikan kedalam skala interprestasi koefisien korelasi maka termasuk dalam kategori “Kuat”, dimana angka tersebut terletak antara 0,60-0,799

2. Berdasarkan hasil yang diperoleh dari perbandingan antara t hitung dengan $t$ tabel dapat disimpulkan bahwa t hitung > t tabel, $1.994>1.701$. dari hasil tersebut dapat disimpulkan bahwa Ho ditolak dan Ha diterima, artinya ada hubungan yang signifikan antara Kompetensi Guru dengan Nilai Ujian Nasional di SMK Negeri 4 Samarinda Tahun pembelajaran 2018/2019. 


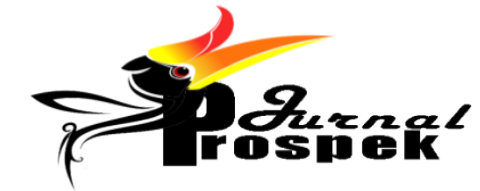

http://e-journals.unmul.ac.id/index.php/jpe

Jurnal Prospek : Pendidikan Ilmu Sosial dan Ekonomi

Volume 3 No 1 Juli 2021

E-ISSN 2721-0855

\section{DAFTAR PUSTAKA}

Alma, Buchari. 2020. Belajar dan Pembelajaran. Bandung: Alfabeta

Aquami dan Handayani. 2018. "Hubungan Kompetensi Guru dan peran Orang Tua terhadap Hasil Belajar Siswa di MIN Se-Kota Palembang”. Jurnal Ilmiah.

Asmani, Jamal. 2009. Manajemen Pengelolaan dan Kepemimpinan Pendidikan Profesional. Yogyakarta: DIVA Press.

Aunurrahman. 2010. Belajar dan Pembelajaran. Bandung: Alfabeta

Hazami dan Herminingsih. 2017. "Pengaruh Kompetensi guru terhadap Efektivitas pembelajaran”. Jurnal Ilmiah Manajemn dan Bisnis. Vol. 3, Hlm 364-384

Murtadho, Juhadi, Santoso AB. 2015. “ Hubungan antara nilai uji kompetensi guru dengan nilai rata-rata ujian nasional mata pelajaran geografi tahun 2013 di SMA Se Kota Semarang”. Edu Geography. Vol. 3 No. 7, hlm. 63-68.

Putri, dwi, santina, suwatno. 2017. "Pengaruh kompetensi pedagogik dan kompetensi sosial terhadap prestasi belajar siswa pada mata pelajaran pengantar administrasi perkantoran kelas X administrasi perkantoran di SMK Negeri 1 Subang”. Jurnal Pendidikan Manajemen Perkantoran. Vol 2 No.2, Juli 2017, Hlm. 113-123

Rusman. 2013. Model-model Pembelajaran. Jakarta: Raja Grafindo Persada.

Syaidah. Ani. 2018. "Pengaruh kompetensi guru terhadap hasil belajar ekonomi di SMA Negeri Rambi Puji Tahun ajaran 2017/2018”. Jurnal Pendidikan ekonomi. Vol. 12, No.2. 